\title{
Strengthening Children's Religious And Moral Values In Shamil And Dodo Cartoon Film
}

\author{
Fitria Septianti ${ }^{1}$, Nur Hafidz ${ }^{2 *}$ \\ ${ }^{1}$ Department of Early Childhood Education, IAIN Purwokerto, Purwokerto, Indonesia \\ ${ }^{2}$ Department of Early Childhood Education, UIN Sunan Kalijaga, Yogyakarta, Indonesia \\ *Email : nurchafidz135@gmail.com
}

DOI : $\underline{10.33086 / \text { cej.v3i1.2109 }}$

Submission: May 18, 2021

Revised: May 25, 2021

Accepted: May 25, 2021

\begin{tabular}{l} 
Keywords: \\
\hline Religious and Moral \\
Values, Children, \\
Cartoon Films of \\
Syamil and Dodo
\end{tabular}

\begin{abstract}
The current era of education for children is experiencing a moral crisis in the aspects of religious and moral development. Religious and moral values of children will be formed through interaction and environmental responses to an active five-sensory performance system. Cartoon films are a strategy for developing children's creativity. By presenting imaginative, interactive, and fun story events through the behavior and attitudes of the characters in cartoon films. The cartoon film Syamil and Dodo became a cartoon film by NCR Production which was made to educate children because it was rich in Islamic educational values and religious and moral values which were suitable to stimulate early childhood. The problem in this research is: "How is the strengthening of religious and moral values in the cartoon film Syamil and Dodo?". The research analyzes the strengthening of religious and moral values in the cartoon film Syamil and Dodo. This type of research is library or Library Research using the cartoon film Syamil and Dodo as the primary data source in this study. Meanwhile, secondary data were obtained from journals, books, and previous thesis. The data collection technique in this research is documentation by observing footage from the cartoon film Syamil and Dodo. Based on the research conducted by the author, the cartoon film Syamil and Dodo is a cartoon film suitable for watching early childhood, the film contains religious and moral educational values for children aged 4-6 years. Strengthening the Syamil and Dodo cartoons can be a medium to reflect and actualize how to properly instill religious and moral values for children in the scope of family and school education.
\end{abstract}




\section{Kata Kunci:}

Nilai Agama dan Moral, Anak-anak, Film Kartun Syamil dan Dodo

\begin{abstract}
Abstrak
Era pendidikan sekarang anak-anak mengalami krisis moral pada aspek perkembangan agama dan moral. Nilai agama dan moral anak akan terbentuk melalui interaksi dan respond lingkungan pada system kinerja panca indra yang aktif. Film kartun menjadi strategi pemengembangan kreativitas anak. Dengan menyajikan peristiwa cerita yang imajinatif, interaktif, dan menyenangkan melalui perilaku dan sikap tokohya pada film kartun. Film kartun Syamil dan Dodo menjadi film kartun karya NCR Production yang dibuat untuk mengedukasi anak-anak karena kaya akan nilai pendidikan yang bernafaskan keislaman serta Nilai Agama dan Moral yang cocok untuk menstimulus anak usia dini. Adapun masalah dalam penelitian ini adalah: "Bagaimana penguatan nilai agama dan moral pada film kartun Syamil dan Dodo?". Penelitian menganalisis penguatan nilainiali Agama dan Moral pada film kartun Syamil dan Dodo. Jenis penelitiannya kepustakaan atau Library Research dengan menggunakan film kartun Syamil dan Dodo sebagai sumber data primer dalam penelitian ini. Sedangkan data sekunder diperoleh dari jurnal, buku, serta skirpsi terdahulu. Teknik pengumpulan data dalam penelitian ini adalah dokumentasi dengan mengamati cuplikan dari film kartun Syamil dan Dodo. Berdasarkan penelitian yang penulis lakukan bahwa film kartun Syamil dan Dodo merupakan film kartun yang cocok untuk ditonton anak usia dini, film tersebut mengandung nilai edukasi keberagamaan dan kemoralan untuk anak-anak usia 4-6 tahun. Penguatan pada film kartun Syamil dan Dodo dapat menjadi salah satu media merefeksikan dan mengaktualisasikan bagaimana cara menanamkan nilai Agama dan Moral untuk anak dengan baik dalam lingkup pendidikan keluarga dan sekolah.
\end{abstract}

\section{A. Introduction}

The current era of education for children is experiencing a moral crisis in the aspects of religious and moral development. Aggressive behavior is closely related to a person's morale, the phenomenon of aggressive behavior appears in various circles, starting from children (Fitriyah, 2019), adolescents (Fitriyah, 2017), and adults (Fitriyah \& Purwoko, 2018). The development of the child is very rapid and fundamental in the next life. Therefore, religious and moral values are closely related to children during their developmental period. Religious and moral values of children will be formed through interaction and environmental responses to an active five-sensory performance system. Cartoon films are a strategy for developing children's creativity. By presenting imaginative, interactive, and fun story events through the behavior and attitudes of the characters in cartoon films. Cartoon movie characters imagine humans doing activities that present certain qualities and characters. In terms of moral values understood by children, they are related to identifying themselves. Children who watch and listen to this cartoon movie will imitate or imitate the attitude of the good character's actions. And internalize the religious and moral values of the characters in their own understanding. Through children's understanding, it is then 
used as a moral attitude in children's stories as a measure of moral attitude. From here, the process of children is formed through characters in children's films who then learn to internalize moral values from their experiences (Nurwita 2019).

It is necessary to know that in order to achieve children with personal characteristics, of course how we see children learning experiences with pleasant or troublesome environmental conditions. Because, children are excellent imitators, children will imitate and actualize everything from their five senses around them. Then a conducive environment will get a good moral attitude and character. Ki Hajar Dewantara said that education is ingarso sungunkarso, tut wuri handayani " education is actualized by providing exemplary examples, providing support, and encouraging children to learn. Education is a change in behavior, knowledge and quality of children in learning through family education, school education, or environmental education. The main education for children is family. This is because $80 \%$ of the dominant children's activities come from the family. Then there is the possibility that the main character is built through the family. Family is the first role modeling for children in forming their first personality (Hafidz and Aerin 2020).

Learning media has an important role in improving learning outcomes including student character, in this era digital learning media is needed (Kusumaning Ayu et al., 2019; Jannah et al., 2021). There is previous research by Ningsih (2018), the influence of the enrichment of the cartoon film media of Syamil and Dodo on children's moral development resulted in a strong influence on moral development through syamil and dodo films aged 5-6 years. At that age, children must obey the guidance or rules of their parents and their social environment. The words of other people, such as: good, not allowed, and naughty, will be socialized by the child with the concept of right or wrong. The inculcation of the concept of morality in these children may experience difficulties because the characteristics of defiance of orders and selfishness of this researcher are similar to the variables studied in the form of the object and the subject. Through the media of the Syamil and Dodo cartoons, children get new experiences through their audio visuals.

Furthermore, researcher Supartiana (2019), about learning akidah morals using the animated film media Syamil and Dodo in class II students of MIN Demangan, Madiun City. As a result, this medium becomes an idea tool to get good ideas. By presenting unique, fun, creative stories so that parents can access them through television, internet networks, and DVDs circulating in the market. With this kind of learning, children can be conditioned to watch together to understand the content of the material and the children understand the storyline of Syamil and Dodo. There are many messages and impressions to stimulate the thoughts, feelings, and wishes of the child so that they can encourage the process of the child's character. From here, researchers can create a concept that the television media for cartoon films can be absorbed by children in terms of stories and the attractiveness of their cartoons.

No less important is Rahmatunnisa, Sari, and Nurhayati (2020) researched the improvement of the ability to pray for children aged 5-6 years through the animated film Dodo Syamil. From this medium, children can pray diligently. There was a significant improvement in the ability to pray for children. In the first cycle the children's prayer ability was 78.57 , the second cycle the children's prayer ability became 97.06 so that the Syamil and dodo flim media could increase the children's prayer diligence and discipline. From here, the child's interest in the story of Dodo and syamil actualizes the child's religious and moral development, which of course the parents play a role in optimizing support.

The three studies above can be found that the cartoon films of Syamil and Dodo are the most important source of religious and moral values for children. This is where the findings of 
the three researchers then develop the conceptual ideas used in transforming religious and moral values in Syamil and dodo into children. The results of the study found that the effectiveness of Islamic philosophy and dodo in loading children's religious and moral values should be used as children's audio-visual media, and told to children. With the process of this activity, the religious and moral values of cartoon films are transformed and internalized for early childhood. In this finding, children are perceived as individuals who have accepted it in cartoons. In fact, early childhood are individuals who already have five senses that are sensitive to the surrounding environment, through which through these sensitive and active senses, children learn from religious and moral attitudes and the actions of people in their families (Julia et al. 2020). This cartoon film has a role as a constituent, but also the story becomes a means of reinforcing educational media, namely strengthening existing religious and moral values. The position of Syamil and dodo cartoons for early childhood is a reflection medium to reinforce religious and moral values that are owned and practiced in their daily life activities.

From the meaning of religion and morals, it is explained in Chapter II Article 3 of Law Number 20 of 2003 concerning the National Education System. Moral identification is a process of human moral reasoning where the more mature a person eats, the higher his moral reasoning. So Kohlberg sparked three important levels of moral development at each level there are two stages. That is, internalization is a developmental transformation of behavior controlled by one's self into behavior controlled by oneself which originates from the balance of conscience. From the initialization level it has three stages, namely, (1) the pre-conventional stage or legal compliance from the age of 0-6 years and oriented towards the hedonistic-istumental age of 6-9 years. (2) the conventional stage or orientation of children aged 9-12 years and oriented to order and authority between 12-22 years of age. (3) post-conventional stages or social-legalistic control authorities aged 22-35 years and conscientious orientation from age 35 years-old age (Darmiyati 2020).

In these three levels determine the good and bad attitudes of behavior based on the level of rewards and the legal consequences of the actions performed. This is where researchers focus on positioning the Syamil and Dodo Cartoon Film for Early Childhood by PT NADA CIPTA KARYA, an Indonesian company engaged in the animation and entertainment-based animation industry. The story of Syamil and Dodo is a children's cartoon film moving on the Islamic religion with the main characters Syamil and Dodo. This story is based on daily activities but is packaged in an interesting, unique, and fun way for children to laugh (Wahidah and Maemonah 2020). On the other hand, it is important to help foster children's character, both understanding Islam and parents are easy to apply in the world of children. The religious and moral values studied are the value of validating Allah, the value of good behavior, the value following the attitude of the Prophet Muhammad, the value of respecting religious fellows. As for the moral values, the value of honesty, helpful value, courtesy, and sportsmanship as well as maintaining a clean environment. On this basis, this researcher examines the audio visual-reflection, namely examining the form of audio-visual and reflecting on children's lives both psychologically and socially.

\section{B. Methodology}

This study used a qualitative descriptive method with a content analysis research model for cartoon children's story content. The method uses to obtain accurate data to explore and elaborate on the religious and moral values of children in the Syamil and Dodo Cartoons for Early Childhood. (Lexy J. Moleong 2018). This descriptive audio-visual document research model positions the cartoon story of Syamil and Dodo which is analyzed and researched directly and 
objectively regarding the phenomena contained in it. In descriptive analysis, there is content analysis which lies in the meaning of the content, reading symbols, and structures contained in literary works into text to understand the phenomenon of children's religious and moral values in audio-visual both through DCD, television, and on the internet network. The religious and moral values in the cartoon film Syamil and Dodo by PT Nada Cipta Raya can be analyzed. This type of research is literature or Library Research using the cartoon film Syamil and Dodo as the primary data source in this study. Meanwhile, secondary data is obtained from journals, books and other references. The data collection technique in this research is documentation by observing footage from the cartoon film Syamil and Dodo.

The concept of research involves two important points, namely theoretical and empirical. Theoretical is a series of various theories that are used as a researcher's needs or a foundation in analyzing and understanding objects. The empirical relates to the number of theories on phenomena and objects that are the focus of empirical research in the context of understanding objects and phenomena scientifically (Sugiyono 2017). Therefore, there is a result of meaning and understanding comprehensively through religious and moral values in early childhood in the cartoon films Syamil and dodo.

\section{Result}

\section{Getting to know the cartoon characters of Syamil and Dodo}

To find out more about Syamil and Dodo cartoons, first get to know the important characters in cartoon films, there are seven characters who have different characters and characters as follows (Supartiana 2019; Fitriyah \& Djazilan, 2020). First, Syamil became a boy with medium stature. Having curly hair, in the film Syamil is a loyal friend, honest, and trustworthy. However, Syamil is not whiny when arguing or defending himself. Syamil is the main character. different from his friend Dodo, Syamil's character better understands the science of religion, even though his religious knowledge is still limited.

Second, Dodo is a boy with a fat body. Has a bald head, very little hair. Dodo is known to be the most cheerful, funny but reckless. Dodo is the main character who accompanies Syamil. Dodo likes to prank and is ignorant of animals, high self-confidence makes Dodo arrogant even in understanding the science of religion, often his self-confident attitude which is considered right, tends to originate and is actually wrong. Even though he has a different character from Syamil, the presence of Dodo in this film makes the storyline interesting because his innocence and lack of religious knowledge make his behavior wrong.

Third, Kak Nadya became Syamil's older brother. The presence of Kak Nadya is as an older figure who has a better understanding of religion, and has a role to provide enlightenment and explanation of the case being faced by Syamil and Dodo and their friends.

Fourth, Syamil's father. The role of Syamil's father in this film is almost the same as Nadya's, providing explanation and enlightenment of the case being faced by Syamil and Dodo and their friends.

Fifth, Mrs. Syamil. The role of Ms. Syamil in the cartoon film Syamil and Dodo is also the same as her father, namely as a parent who explains if something is wrong or if there is something wrong with Syamil, Dodo and his friends.

Sixth, Uncle Adul. A crazy person who is often harassed by Dodo, even though he is crazy, Uncle Adul understands a lot about religious knowledge. The story is that even though he is considered a madman, Uncle Adul has knowledge of religion. His role as a fringe person makes the story funny. 
Seventh, Syamil and Dodo friends such as, Anto, Amir, Iwong, and many other supporting roles in this film. They are friends of Syamil and Dodo in their daily lives who always play together, study religion and go to school in the same place.

\section{Religious and Moral Values in the Cartoon Film Syamil and Dodo}

Education is needed to form the initial foundation so that children become religious and moral persons with strong beliefs and have a moral and noble personality. The researcher describes the value content of the developmental aspects of Religious and Moral Values according to the development of children aged 4-6 years in the cartoon film Syamil and Dodo, and then the researcher will analyze the concept of family education related to the development aspects of Religious and Moral Values earlier. The explanation of the strengthening of religious and moral values uses a theory that has been designed by previous researchers. The following is the researcher's analysis regarding the research title in the cartoon film Syamil and Dodo:

\section{a. Get to know Tauhid on the theme "Mengesakan Allah SWT"}

It was said that in the afternoon, Dodo was called by his friends to compete in soccer. During the match Dodo always kicks with enthusiasm to say the power of the moon god, when his friend also wants to put the ball into the goal Dodo also says aloud the kick of the power of the moon god. Dodo also believes that if he chants the power of the moon god, he will score a goal. And finally the Dodo team won the match, after which Dodo boasted to his friends that their team won because he chanted the power of the moon god, his friend didn't agree, especially Syamil. Kak Nadya came to offer ice, then he enlightened that worshiping other than Allah is shirk.

Islam or we as Muslims should not worship anything other than Allah. Only in Allah do we have confidence, if we believe there is a power other than Allah then it is a big sin or an act of shirk (Nurwita 2019). Only to Allah do we ask for help, ask for strength, only to Him we worship. Kak Nadya in the dialogue, namely "Now, listen, yes, the victory that you got earlier was solely because of Allah's help, not the help or strength of anyone, including the moon god. This is a belief that is fundamental to us as Muslims. If we believe that there is a power other than Allah that can provide benefits or calamities, then that is an act of shirk. Now, listen up, the victory that you got earlier was solely because of Allah's help, not the help or strength of anyone, including the moon god. This is a belief that is fundamental to us as Muslims. If we believe that there is a power other than Allah that can provide benefits or calamity then that is considered shirk. "From this dialogue we can conclude that as Muslims, we only have faith in Allah, Islam prohibits worshiping statues, trees or other objects, believe in a shaman or talisman, early childhood needs to be introduced to the religion they adhere to as well as the orders and prohibitions in Islam.

\section{b. Practicing fasting}

When the time for zuhr arrived, Dodo went to the mosque very weak because he was fasting. When he took the ablution water, he wanted to drink the ablution water so badly that he looked around to drink it without being caught by the people around him. Suddenly Syamil came and surprised Dodo, who was drinking the ablution water. Dodo denied and bragged that he broke the fast until evening time and did not need sahur. Dodo returned home and told his mother, Mrs. Dodo gave advice that everything he did would be known by Allah. While at home, Syamil tells everything to Syamil's father that Dodo fasts until the time of Isha comes 
and no longer suhoor in the morning, Syamil's father also gives an explanation to Syamil about good fasting procedures and anything that can make fasting possible.

Syamil, who did not understand the procedure for fasting, asked his father because the fasting that Dodo did was very different from him, Syamil's father explained in detail the recommended procedures like the Prophet as this dialogue excerpt: "First we must intend to fast before dawn, as has been said prophet. The second is to eat sahur, which is to eat at the night of the month of Ramadan from midnight until before dawn, and eat sahur better at the end of the time In a hadith, the Prophet said: "Eat sahur, because in sahur there is a blessing". Eating sahur is important, so that our bodies have the energy or energy to carry out activities the next day, for example school, study, work, cooking and so on and this is what distinguishes Muslims from other people. And thirdly, guarding ourselves not to do things that do not break fasting or destroy the rewards of fasting such as getting angry, stealing or fighting besides that we have to hurry to break the fast when the time comes. In a Hadith Qudsi Rasululloh said: "The servants who love the most are those who hasten to break the fast". Syamil, who is fasting, already understands the manners of fasting taught by his father (Fajar 2017).

c. Value of Honesty, Helper, Courtesy, and Sportsmanship

After playing soccer, Syamil and Anto asked Dodo to buy ice, because Dodo won the match, but Dodo did not have money and he seduced Kak Nadya to buy the ice. Kak Nadya gave Dodo five thousand to buy four ices. After Dodo bought the four ices, it turned out that the man who sold the ice was wrong to return more money to Dodo. Dodo realized when he was on his way home and thought the money was a bonus then he bought oranges with the money. Dodo gives ice to his friends who have been waiting for a long time. Dodo returned the change to Kak Nadya, Syamil was surprised to see Dodo eating oranges, he asked where Dodo got the oranges, even though previously Dodo said he had no money. Kak Nadya was also confused, then Kak Nadya advised Dodo for being dishonest.

Dodo, who is not honest, gets advice from Kak Nadya because the money Dodo bought for oranges is money from the iceman's uncle. Kak Nadya, who heard that Dodo received money that was not his, gave an explanation about being honest, such as in the following dialogue: "Well, honesty is the harmony between speech and deed, so if something is given in accordance with existing circumstances it is said to be honest, but if not then it is said to be a lie. , honesty is in speech as well as in deeds. Allah loves those who act honestly and they will get reward and pleasure from Allah, while those who lie will get sin and His wrath. " So, being honest for us is an act that we have to make as a guide for life to get Ridha Allah SWT at every step we take in this world (Kristiowati and Himmah 2020). Kak Nadya is also an example of him helping Dodo, who has no money to buy his friend's ice, in the cartoon, Syamil and Dodo also exemplify their sportsmanship in playing soccer matches.

d. The value of cleanliness and protecting the environment with the theme "Prayers 5 times"

Dodo, who was about to go to school, saw a running cat and with his mischievous nature, Dodo kicked the cat. Then Dodo and Syamil meet on the road and go to school together, Dodo picks a pebble to throw it at the dog, the dog runs into a shock. Syamil, who was annoyed, advised Dodo that people who pray would not harm animals. When the bell rang, the Teacher explained the meaning of prayer and enlightened that prayer actually prevents evil and evil deeds, explaining the procedures for prayer and purification. Beginning with ablution, prayer intentions and ending with greetings (Akhirin 2013). The teacher asked 
the number of obligatory prayers along with the number of rakats. And he explained that prayer would teach discipline in everyday life.

Syamil and Dodo in the 5 daily prayers taught us to love our fellow beings, because morals towards the environment also means that we take care of animals, plants, and other objects. As Muslims who are taught by their religion to love animals, we should also be able to protect ourselves from being arbitrary to animals, protecting the environment, protecting the natural surroundings and so on. Like the Prophet Muhammad, his behavior loves animals, because animals can bring rewards to those who love them, let alone care for them with love. In the dialogue snippet above, we can make it a lesson to love animals, the following is an excerpt from the teacher's dialogue explaining how to love animals: "In fact, prayer prevents evil and evil deeds, meaning that if people pray they will not do anything cruel, so if they often abuse animals, they must pray it. not right yet. " In the snippet of the dialogue contains a moral message so that children love animals, the prayers that are carried out should be due to the sincerity of Allah so that their attitude will reflect how the prayer is. Teacher's explanation is part of protecting the environment where we are, education to protect the environment is part of the compassion of fellow living beings (Andriyani 2018).

\section{e. Knowing the Islamic Religious Holidays on the theme 'Isra Mi'raj'}

Initially, Syamil was looking at the calendar Dodo reported that the next day was school holidays due to red dates. Syamil then approached his father who was watching television and asked what he was watching. Syamil's father answered that he was watching isra mi'raj and Syamil also asked what isra mi'raj. Syamil's father explained in detail about isra miraj and how the journey of the Prophet Muhammad to the seventh heaven and received orders to pray.

As Muslims, the cartoon film Syamil and Dodo, we should know the religious holidays like Syamil who want to know the Islamic religious holidays, namely isra mi'raj. Knowing religious holidays is a manifestation of our love for Allah SWT and the Prophet Muhammad. As a parent, Syamil's father provides knowledge to his child as in this dialogue snippet: "Wow, if you explain Syamil it must be complete, right? Okay daddy will explain everything. Isra mi'raj consists of two words, namely isra and mi'raj, occurring on the night of 27 Rajjab $620 \mathrm{AD}$ or 2 years before the hijrah. Isra is the Prophet's journey from the Grand Mosque through Tasrif or it is called the City of Medina after the Prophet migrated, Medina-hill Tursinah-Bethlehem and ended at the Aqsa Mosque in the City of Jerusalem from Masjidil Aqsa doing Mi'raj up to the seventh heaven. Prophet Muhammad met Allah SWT and received orders to pray, at first Allah required 50 prayers for Muslims in a day, then after the Prophet Muhammad repeatedly asked for prayer time relief for Muslims, Allah reduced it to 5 times a day and a night. So, the five daily prayers that we do today, are souvenirs from the isra mi'raj of the Prophet Muhammad." Knowing the big day of our religion, like in the film Syamil and Dodo, is very important for children because children who are still experiencing growth are usually eager to know everything in detail. So it is very appropriate to provide Islamic knowledge about religious holidays to increase children's love for Allah SWT. From here, children can also be taught the importance of Muslim holidays (Hasanah 2020).

\section{f. Respecting Others' Religions on the theme of 'Azan'}

Nadya, who was watering the flowers, listened to the call to prayer at the Asar prayer, at that time Syamil was engrossed in playing cars so he didn't listen to the call to prayer. Then Kak Nadya invited Syamil to pray in congregation, at first Syamil refused because he was 
enjoying playing. But finally Kak Nadya gave advice to play after prayer, they prayed in congregation with their mother and father. After praying, Syamil asked why prayers were marked with the call to prayer. Kak Nadya then teased him because when he was playing the call to prayer, Syamil was cool. Syamil's father explained that when the Prophet had moved to Medina, his people marked prayer times based roughly on the weather. Finally it was decided with the call to prayer because Abdullah bin Said dreamed of a call to people when praying and since then the call to prayer has become a call to prayer (Amin 2018).

We as true Muslims should respect religion, especially our own religion, such as the Syamil family who respects when the call to prayer echoes in response to the call to prayer by Syamil's father, and immediately fulfills the call to prayer by praying in congregation. As mentioned earlier, the following is a snippet of Syamil's father's dialogue: "Allahuakbar, laa haula wala kuwwata illabillah, let's pray asar." From the film there is a message that as Muslims, when we listen to the call to prayer, we must be serious and leave the work we are doing. Like Dodo, who is busy playing toy cars, gets advice from Kak Nadya and Dodo complies.

\section{Discussion}

\section{Strengthening Religious Values for Children}

Kak Nadya's character in this episode serves as a protector for his younger siblings so they don't think wrong and can endanger them for other bad deeds. In addition, in the dialogue snippets in this episode, Ms. Nadya educated her younger siblings using the dialogue method, Ms. Nadya explained about the problems faced by her younger siblings by giving advice and instilling an understanding of religious values or religious functions. Kak Nadya also explained that the consequences for worshiping someone other than Allah. This means that the family environment needs to pay attention to how to instill religious and moral values in children who are in a period of development and growth.

Introducing religion to children is the duty of parents and teachers both at school and in the family which can be introduced in the following ways:

a. Introducing God. God for children is something strange and abstract, but at kindergarten age, the growth of children's intelligence is still related to their sense organs, and has not been able to understand abstract things. various ways, namely; Introducing children through the natural surroundings who can see the beauty of the greatness of Allah SWT, Introducing through love through touch, speech and attitudes and attributes of Allah SWT, Introducing children through stories, Introducing through habits of prayer and responsibility of worship and those that are prohibited in religion, Introducing through image or video media etc.

b. Introducing Worship to Allah SWT. Children need to be introduced to worship to Allah SWT, in the introduction of worship to Allah for kindergarten age children must be done in fun and simple ways by considering the level of attainment of the child's physical and spiritual development. This can be done through direct involvement of children in carrying out compulsory worship. Worship needs to be introduced and inculcated through the habit of praying in congregation in a fun way and introducing the obligations of a Muslim.

c. Inculcate good morals. The cultivation of moral values will work well if we have a good personality or character, have praiseworthy qualities, understand children's psychology, love children and are liked by them, so that it becomes a good example for children. Parents can teach children to pray before and after doing an activity, because being dirty is the root of salvation. In addition, parents can teach children to have gratitude for what they already have and say hamdalah after doing activities, it will make children accustomed to being grateful because gratitude is the key to happiness. 
Strengthening religious and moral values in the cartoon film Syamil and Dodo, namely introducing religion to early childhood, requires the cultivation of a strong aqidah, children need to be directed to the habit of asking for prayer and help only to God, namely Allah SWT, understanding the dangers posed If you ask other than Allah, it will result in shirk which is forbidden by Allah and the first thing is to inform the child that the religion of a Muslim is the religion of Islam that is blessed by Allah. It is also necessary with the guidance of parents, it is necessary to provide understanding to children in Islam, all worship and ask for help only from Allah SWT, the giver of life.

The concept of knowing the big day of Islam with Syamil and Dodo on the theme Isra Mi'raj which tells that Syamil who has a curiosity about the big day of Isra Mi'raj and asks his father. Syamil's father as a parent explains what Isra Mi'raj is and how the story behind the Isra Mi'raj day. Parents should instill religious values in children from an early age, so that children have a soft heart and are obedient to worship Allah SWT.

Syamil's father who was watching the Isra Mi'raj commemorative television program explained the meaning behind the Isra Miraj celebration by using the functions of love and religion in family education. Where, the loving father of Syamil and the cheerful Kak Nadya really loved Syamil so that a warm atmosphere was formed. Syamil's father explained that the Isra Mi'raj warning was carried out by the Prophet Muhammad. In ancient times traveling from the Haram Mosque to the Aqsa Mosque, Syamil's father used the story method to provide understanding to his son.

We can explain the big day in Islam to children briefly but it can attract children's attention, such as introducing hijriyah dates by using Islamic chants, then state the meaning of each date why these dates are celebrated as religious celebrations, so that children can know their origins. the holidays of Islam. Telling stories to children is an effective and very fun method at their age, because children at this age still know only concrete things. Important events on Islamic holidays are special. Providing knowledge about the big day in Islam is also the planting of aqidah or pillars of faith in children, by providing an understanding because of the religious holidays, children will be more amazed and interested in worshiping Allah SWT. The application of aqidah from the family can be initiated by laying the foundations of faith in children, namely in faith in Allah SWT, parents can teach their children the sentence of tawhid and it is better since the child is born and hears the call to prayer from his father, because the call to prayer is a testimony to worship only to Allah Swt and it's good to knock the heart the first time the baby is born.

Then, Respect other people's religions. The cartoon film Syamil and Dodo on the theme of Azan, explains that the character Kak Nadya as an older brother who is an example and a guide for his younger brother invites Syamil to immediately carry out the Asar prayers in congregation. Nadya performs the function of protection (protection) because it provides protection to avoid useless actions because she refuses to pray in congregation, besides that Ms. Nadya also gives affection that as a sister who cares for her younger siblings, Ms. Nadya needs to admonish and provide religious understanding for Syamil's father also gave religious cultivation to Syamil when Syamil wanted to know why prayers were marked by the call to prayer using the method of formation and habituation, such habituation respected the call to prayer and immediately carried out the mandatory orders for Muslims. By knowing the Islamic religion that gives love to others, children will understand to respect other people's religions, they need parental guidance to know the compassionate Islam religion (Boiliu and Polii 2020). Here are some forms of tolerance in carrying out da'wah, including: 
a. Tolerant with the brotherhood of fellow Muslims. In connection with the relationship of tolerance with fellow Muslim brotherhood, in this case Allah SWT said which means, "Believers are actually brothers. Therefore reconcile (improve the relationship) between your two brothers and fear Allah, so that you may receive mercy (Surah Al-Hujurat: 10). In this verse, the believers are brothers and Allah commands them to do islah (to restore their relationship) in case of a misunderstanding between them.

b. Tolerance between religious communities. Tolerance between religious communities can be interpreted as an attitude to be able to live with people who adhere to other religions by having the freedom to carry out their respective religious principles (worship).

c. Tolerant in family life. An attitude of tolerance is needed to be cultivated in the family in order to form a harmonious family atmosphere.

d. Tolerance in people's lives.

e. Tolerance in the life of the nation and state. The life of the nation and state is essentially the life of the people of the nation. In it there is the life of various kinds of customs, culture, ethnicity, religious adherents and adherents of different beliefs.

From several kinds of tolerance, our religion recommends loving one another so that it is necessary to instill good morals to form a person that respects each other. And the following is the application of the application of communication psychology in maximizing the internalization of tolerance values in children.

Children in the family can respect (tolerate) other people's religions by planting it starting from respecting their religion, then educating children with moral education. If the child has a good attitude, then he will respect each other. Tolerance can be done starting from respecting fellow Muslims, respecting inter-religious communities, respecting family, respecting society, and respecting the nation and state.

\section{Strengthening Moral Values for Children}

In the cartoon film, Syamil and Dodo, on moral values for children, found two important analyzes, namely the attitude of honesty, soap attitude, respect and motivation. And the attitude of discipline by praying five times a day. Strengthening moral values can teach children to be honest by educating their children through worship in Islam. Such as prayer, fasting, and pilgrimage. Through prayer, we are educated to be honest (heart, intention, thought, movement, and deed) before Allah SWT. The obligation to fast in Ramadan is also synonymous with education and self-training to be honest, because fasting is not pure physical worship, but is more of heart worship, and only the perpetrator and Allah know that he is fasting. Hajj also teaches believers to be honest about all the sins they have committed while doing istighfar to Him. Parents must be as creative as possible in guiding their children to have a good moral character. Exemplary methods can also be practiced by parents to educate their children, this method can be used by parents and children to practice together by taking exemplary stories from the stories of the Prophet and his companions with fun stories, because early childhood is easier to absorb the values of religious education from parents through their behavior, feelings, attitudes, and direct practice with parents.

The film Syamil and Dodo with the theme of being honest, children need to be given honesty education material because it is a commendable character, honesty is also an attitude that needs to be trained in children from an early age through habituation in children's daily life, in words, actions, and times. intend to do something. It must also be practiced with the example of parents or family members because during their learning period, children like to imitate the behavior that is reflected by those around them. From the film, Syamil and Dodo can also be used as an example for parents if someone who is dishonest must be advised, given an explanation and direction, and the consequences of lying so that the child does not repeat the act and becomes a lesson for them (Wahidah and Maemonah 2020). 
Then maintain cleanliness and the environment with the theme of the 5 daily prayers. If we keep the environment clean, then we also participate in caring for the environment. The moral value in maintaining cleanliness and the environment is an important part to be conveyed and instilled in children's lives from an early age, as in the snippet of the theme of prayer 5 times in the cartoon film Syamil and Dodo. In the following episode, Syamil as Dodo's close friend performs a protective function and the teacher performs a religious function. Where they explain how people who do not love animals by using the dialogue method. Parents as the main educators in the family must teach that Islam is a religion that is rahmatan lil 'alamin, which is a religion that brings blessings to all of nature.

Islam, which brings blessings to living beings, has rules in it that teach us not to love animals alone, we are also taught to protect the environment and clean the environment. For children, parents must instill special tips to protect the environment, such as in real religion, animals, plants, and nature together pray and act to Allah. Instill in the child's soul apart from moral education, spiritual education can also be added in conveying advice, from animals, plants and the universe all pray to Allah, especially we as creatures who have reason, we must also participate in protecting the environment, protecting creatures that loved by Allah who always praises only Allah, the admiration that the child gets from the story of his parents will enter into the child's mind.

Parents can do the moral to maintain cleanliness and the environment, starting from maintaining the cleanliness of the body, place of residence, and the surrounding environment. Because we as humans are also very dependent on the environment, we should not be arbitrary on the environment, we also need to always care for and protect it. For example in disposing of garbage, exploiting nature, and not polluting the environment because all of that will also have a bad impact on humans if we don't protect the environment (Julia et al. 2020).

In the family by parents it can also be done by gardening and raising animals to instill affection for fellow creatures. It turns out that in exploring gardening, raising animals can involve brain sensitivities, such as:

a. Teaching children to love plants and nurture them, the beauty of plant colors and the contrast of natural colors will create a bias of admiration for the Creator and this stimulates the child's right brain.

b. Caring for God's creation means deeply admiring the Creator. Doing good to pets and comforting them, creates a sense of satisfaction in us. Satisfied because we have made the Creator of nature pleased with our actions to the environment.

c. Introduce to children that nature naturally teaches us about colors. Show your children that nature and plants in Indonesia are beautiful.

d. Show children that we love animals with great feeling (stimulates the right brain). Because children who grow up from families that do not teach compassion will be less empathetic towards the environment and less sensitive to help sentient beings.

So the cartoon film footage of Syamil and Dodo as Muslims who are taught by religion to maintain cleanliness and the environment must always take care of it so that nature also looks after humans. The purpose of moral education is to protect this environment, so that children can respect everything around them and be able to be responsible for their actions, of course parents play a very important role in educating their children. Like Dodo who hurts an animal initially means that it is not correct to pray because prayer can prevent evil and evil deeds and a person's religiosity is measured from his morals as the Prophet said: "Alladzii numu'aa instead" which means religion is a good relationship of interaction. The results of this study reinforce the concept that teaching spirituality to children needs to be done from an early age as a basis for their character education (Fitriyah, et al., 2020). 


\section{E. Conclusion}

Syamil and Dodo cartoons are cartoons suitable for children to watch. This is because the film becomes a medium to reflect on imitating or imitating cartoon stories through television, DVD, and other social media. This can educate the audience, especially children aged 4-6 years in the development of religious and moral values. This aspect is knowing the religion that is adhered to on the theme of "Mengesakan Allah", doing worship on the theme of "Adab fasting", behaving honestly, being helpful, polite, respectful, sportsmanship, and so on. on the theme "Honest", maintaining cleanliness and the environment on the theme "prayer 5 times", knowing the religious holidays on the theme "Isra Mi'raj", and respecting (tolerance) other people's religions on the theme "Azan".

The cartoon film Syamil and Dodo is a medium that can develop Religious and Moral Values in early childhood in family education and at school. Because there are indicators of aspects of the development of Religious and Moral Values that are good for children to watch as children's guidance. Parents and teachers in Syamil and Dodo Cartoons can be a source of how to instill good Religious and Moral Values in children so that they can be conditioned in a fun, effective way, and can actualize them.

\section{F. Recommendation}

This article explains the idea of a cartoon film by Syamil and Dodo in the world of children's stories. This film reflects the children learning religion and morals through their five active senses. Syamil and Dodo cartoons are very suitable for children to watch. This is because the story packaging is creative, easy to absorb, and humorous.

\section{G. References}

Akhirin, Akhirin. (2013). Mengembangkan Kecerdasan Spiritual Melalui Rukun Iman Dan Rukun Islam. Tarbawi: Jurnal Pendidikan Islam 10 (2). https://doi.org/10.34001/tarbawi.v10i2.179.

Amin, Alfauzan. (2018). Sinergisitas Pendidikan Keluarga, Sekolah Dan Masyarakat; Analisis Tripusat Pendidikan. At-Ta'lim : Media Informasi Pendidikan Islam 16 (1): 106-25. https://doi.org/10.29300/attalim.v16i1.824.

Andriyani, Isnanita Noviya. (2018). Pendidikan Anak Dalam Keluarga Di Era Digital. FIKROTUNA 7 (1): 789-802. https://doi.org/10.32806/jf.v7i1.3184.

Boiliu, Fredik Melkias, and Meyva Polii. (2020). Peran Pendidikan Agama Kristen Dalam Keluarga Di Era Digital Terhadap Pembentukan Spiritualitas Dan Moralitas Anak. IMMANUEL: Jurnal Teologi Dan Pendidikan Kristen 1 (2): 76-91. https://doi.org/10.46305/im.v1i2.18.

Darmiyati, Darmiyati. (2020). Penilaian Unjuk Kerja Dalam Pengembangan Agama Dan Moral Anak Usia Din. Jurnal Pendidikan Kewarganegaraan 10 (1): 74-85. https://doi.org/10.20527/kewarganegaraan.v10i1.8532.

Fajar, M. Samson. (2017). Transformasi Nilai Rukun Islam Dalam Peningkatan Sumber Daya Insani (SDI) Berperadaban. Ath Thariq Jurnal Dakwah Dan Komunikasi 1 (1): 15-26. https://doi.org/10.32332/ath_thariq.v1i1.806.

Fitriyah, F. K. (2017). Reducing Aggressive Behavior Using Solution-Focused Brief Counseling (SFBC). JBKI (Jurnal Bimbingan Konseling Indonesia), 2(2), 34-39. https://doi.org/http://dx.doi.org/10.26737/jbki.v2i2.254

Fitriyah, F. K. (2019). Pengaruh Perilaku Agresif pada Anak Usia Dini terhadap Kecemasan dan Empati. Education and Human Development Journal, 3(1), 96102. https://doi.org/https://doi.org/10.33086/ehdj.v4i1.1088 
Fitriyah, F. K., \& Djazilan, M. S. (2020). Kontekstualisasi Nilai Pendidikan Karakter dalam Sirah Nabawiyah. Journal of Islamic Civilization, 2(2), 80-89. https://doi.org/https://doi.org/10.33086/jic.v2i2.1734

Fitriyah, F. K., \& Purwoko, B. (2018). Youth narcissistic and aggression: A challenge for guidance and counseling service in University. 173(Icei 2017), 109-111. https://doi.org/10.2991/icei-17.2018.29

Fitriyah, F. K., Saputra, N., Dellarosa, M., \& Afridah, W. (2020). Does spirituality correlate with students' empathy during covid-19 pandemic? the case study of Indonesian students. Couns-Edu: The International Journal of Counseling and Education, 5(3). https://doi.org/https://doi.org/10.23916/0020200527820

Hafidz, Nur, and Wafa Aerin. (2020). Nilai Moral Anak Dalam Buku Dongeng Fabel Imajinatif Untuk Anak Usia Dini. Jurnal I'TIBAR 4 (2). http://ejurnal.stitqi.ac.id/index.php/itibar/article/view/222.

Hasanah, Aswatun. (2020). Perbedaan Perkembangan Moral Anak Laki-Laki Dan Anak Perempuan Pada Usia Sekolah Dasar. Yinyang: Jurnal Studi Islam Gender Dan Anak 15 (1): 41-58. https://doi.org/10.24090/yinyang.v15i1.3442.

Jannah, Z., Fauziah, N., Ningsih, T. N., Kusumaning, R. F., Suryadi, D. A., Putri, R., Budiarti, N., \& Fitriyah, F. K. (2021). Planetarium Glass Based on Augmented Reality to Improve Science Literacy Knowledge in Madura Primary Schools. 3(1), 19-29.

Julia, J., Encep Supriatna, I. Isrokatun, Iis Aisyah, Arif Hakim, and Adeola Aminat Odebode. (2020). Moral Education (2010-2019): A Bibliometric Study (Part 2). Online Submission. Vol. 8. https://eric.ed.gov/?id=ED606763.

Kristiowati, Nonik Dwi, and Irliana Faiqotul Himmah. (2020). Peran Pendidikan Keluarga Terhadap Perkembangan Nilai Moral Agama Anak Di Paud Islam Terpadu Ananda Kabupaten Jember. Learning Community: Jurnal Pendidikan Luar Sekolah 4 (2): 35-38. https://doi.org/10.19184/jlc.v4i2.21295.

Kusumaning Ayu, R. F., Puspita Sari, S., Yunarti Setiawan, B., \& Khoirul Fitriyah, F. (2019). Meningkatkan Kemampuan Berbahasa Daerah Melalui Cerita Rakyat Digital pada Siswa Sekolah Dasar: Sebuah Studi Pengembangan. Child Education Journal, 1(2), 65-72. https://doi.org/10.33086/cej.v1i2.1356

Lexy J. Moleong. (2018). Metode Penelitian Kualitatif. Bandung: Remaja Rosdakarya. Ningsih, Marlia. (2018). Pengaruh Penayangan Media Film Animasi Syamil Dan Dodo Terhadap Perkembangan Moral Anak Usia Dini. Jurnal Talenta : Journal of Early Childhood Education 9 (2): 125-38.

Nurwita, Syisva. (2019). Analisis Nilai-Nilai Agama dan Moral Anak Usia Dini dalam Tayangan Film Kartun Upin dan Ipin. Jurnal Obsesi : Jurnal Pendidikan Anak Usia Dini 3 (2): 506-17. https://doi.org/10.31004/obsesi.v3i2.252.

Rahmatunnisa, Sriyanti, Diah Andika Sari, and Sri Nurhayati. (2020). Peningkatan Kemampuan Salat Anak Usia 5-6 Tahun Melalui Film Animasi Dodo Syamil. Southeast Asian Journal of Islamic Education 3 (1): 77-96. https://doi.org/10.21093/sajie.v3i1.2914.

Sugiyono. (2017). Metode Penelitian Kuantitatif, Kualitatif, Dan R\&D. Bandung: Alfabeta, CV.

Supartiana, Rini. (2019). Pembelajaran Akidah Akhlak Menggunakan Media Film Animasi Syamil Dan Dodo. Jurnal Dewantara 6 (02): 273-85.

Wahidah, Afifah Fatihakun Ni'mah, and Maemonah Maemonah. (2020). Moral Thought of Early Childhood in Perspective Lawrence Kohlberg. Golden Age: Jurnal Pendidikan Anak Usia Dini 4 (1). https://doi.org/10.29313/ga:jpaud.v4i1.5991. 